\title{
Modern Contradictions and Prospects for the Development of Non-Urban (Rural) Territories
}

\author{
Lyudmila Dulepinskikh*, Larisa Sycheva, and Olga Yunusova
}

Federal State Budgetary Educational Institution of Higher Education «Perm State Agro-Technological University named after Academician D.N. Pryanishnikov, 614990 Perm, Russia

\begin{abstract}
The article is devoted to the problems of the current state and prospects for the development of rural areas of the Russian Federation. The issues of the integrated development of rural areas are currently acquiring special relevance. The main factors in the development of non-urban areas are associated with the political, economic and social development strategy of the country. Considering the dynamics of changes in the number of municipalities, we observe a decrease in the number of rural settlements. The main reasons of this situation are considered: a decrease in the rural population, a decrease in the number of births in the countryside, an annual decline in natural population growth, an increase in deaths in rural areas. The existence of many problems of life in villages and villages is confirmed by a sociological survey of rural residents. The existing system for managing the development of rural areas definitely has positive results, but mainly where production has been preserved and operates. Enterprises that perform production activities in the countryside are most often cityforming. They help the municipality to solve economic and social problems. These organizations participate in program projects for the development of the territory with their own share of co-financing. They are primarily interested in creating decent living conditions in the countryside, an influx of population into rural areas, an increase in the number of ablebodied people and jobs. We have identified the main contradictions that hinder the integrated development of non-urban areas, contribute to the outflow of rural residents and the extinction of villages. But it is the "Population" indicator that is one of the determining ones when calculating subsidies in the territory for equalizing the budget, for solving issues of local importance related to the construction and repair of schools, maintenance of roads, maintenance of housing and communal services, provision of drinking water, etc. The article identifies the main directions for the further development of rural areas in order to enhance the socio economic situation in the countryside.
\end{abstract}

\section{Introduction}

Currently, in the context of a pandemic, the issues of integral development of rural areas are acquiring particular relevance. The development of the agro-industrial complex has become

\footnotetext{
* Corresponding author: dulepinskih.liudmila@ yandex.ru
} 
an important factor in national security. One of the most important conditions for the development of agribusiness is improving the life quality in the countryside. The authorities at all levels understand the seriousness of the task assigned to them, but due to a number of contradictions, rural areas still lag behind urban areas in development. Russian and foreign scientists quite often in their works study the factors of development of non-urban areas. Some of them believe that first of all it is necessary to develop the economy of the territory, while others - the social sphere [5]. We believe that in the integral development of rural areas, the social sphere and the economy are equally important and interrelated.

In this regard, the purpose of our study is to establish a connection between the indicators of social-and-economic development of rural areas of the Perm Territory, to identify key contradictions that affect the development of the region.

\section{Research Methodology}

During the study, we used analytical, monographic and statistical methods.

The author's hypothesis contains the need to develop a strategy for the development of rural areas in the economic, socio-demographic and administrative directions of development, in order to eliminate contradictions in the further development of the agrarian sector of the region's economy.

\section{Findings}

Often, working in the agricultural industry determines the way of life of a person. But the level and life quality in rural areas differs significantly from urban areas, prompting rural youth to migrate to the city. The Government of the Russian Federation has set the task for the authorities of all levels to ensure a uniform standard of living for the population, both in the city and in the countryside, through the integral development of rural areas. But the process of transition to such development becomes problematic due to a number of reasons that may influence the development of municipalities beneficially or hinder this process. Let us highlight the main factors that are associated with the economy, politics, strategy of social development of the state, affecting the development of regions:

- the importance of providing food to the population in the economic development of the country;

- the degree of development of the budgetary system, tax and pricing policy, determination of goals and priorities in the credit market;

- the main measures of the state system of co-financing of projects of domestic producers;

- development of the legal framework;

- development of food markets.

Rural areas play an important role in the social-and-economic development of a particular region and the country as a whole. Currently, the village is experiencing a rather difficult period of its development. In rural areas, such mass phenomena as poverty, unemployment, the inability to receive education, medical care, services in the spheres of everyday life, trade, and culture are growing. In many settlements remote from the administrative center, there are no roads, drinking water, Internet, communications.

We are seeing a massive outflow of residents of small villages. Since 2015, the number of rural residents in the Perm Territory has decreased by 15.2 thousand people, it is $24 \%$ of the total population of the region. The number of able-bodied population living in villages has decreased by $1.4 \mathrm{mln}$ people (Table 1 ).

Table 1. Dynamics of the population of the Perm Territory, th people 


\begin{tabular}{|l|c|c|c|c|c|c|}
\hline \multicolumn{1}{|c|}{ Indicator } & $\begin{array}{c}\mathbf{2 0 1} \\
\mathbf{5}\end{array}$ & $\mathbf{2 0 1 6}$ & $\begin{array}{c}\mathbf{2 0 1} \\
\mathbf{7}\end{array}$ & $\begin{array}{c}\mathbf{2 0 1} \\
\mathbf{8}\end{array}$ & $\begin{array}{c}\mathbf{2 0 1} \\
\mathbf{9}\end{array}$ & $\begin{array}{c}\text { Relation } \\
\text { of 2015 to } \\
\mathbf{2 0 1 9} \%\end{array}$ \\
\hline Total population & $\begin{array}{c}2,63 \\
4.4\end{array}$ & $\begin{array}{c}2,634 \\
.4\end{array}$ & $\begin{array}{c}2,63 \\
2.1\end{array}$ & $\begin{array}{c}2,62 \\
3.1\end{array}$ & $\begin{array}{c}2,61 \\
8.8\end{array}$ & 99.4 \\
\hline $\begin{array}{l}\text { Rural population } \\
2\end{array}$ & 642.4 & $\begin{array}{c}638 . \\
6\end{array}$ & $\begin{array}{c}634 . \\
9\end{array}$ & $\begin{array}{c}630 . \\
0\end{array}$ & 97.6 \\
\hline $\begin{array}{l}\text { The share of the } \\
\text { population living in } \\
\text { rural areas of the } \\
\text { total population, } \%\end{array}$ & 24.5 & 24.4 & 24.3 & 24.2 & 24.1 & 98.4 \\
\hline $\begin{array}{l}\text { Working-age } \\
\text { population }\end{array}$ & 1,51 & 1,484 & 1,46 & 1,43 & 1,41 & 93.9 \\
\hline $\begin{array}{l}\text { The number of } \\
\text { employees in } \\
\text { agriculture, forestry, } \\
\text { hunting, fishing }\end{array}$ & 27.3 & 25.8 & 24.1 & 21.4 & 20.1 & 73.6 \\
\hline $\begin{array}{l}\text { Number of } \\
\text { unemployed }\end{array}$ & 25.4 & 17.9 & 16.7 & 15.3 & 16.5 & 64.9 \\
\hline $\begin{array}{l}\text { Including people } \\
\text { living in rural areas }\end{array}$ & 9.6 & 6.2 & 5.7 & 5.3 & 5.5 & 57.3 \\
\hline $\begin{array}{l}\text { Share of } \\
\text { unemployed living } \\
\text { in rural areas, \% }\end{array}$ & 37.9 & 34.4 & 34.1 & 34.9 & 33.0 & 87.0 \\
\hline
\end{tabular}

Of the total working-age population, only $1.4 \%$ work in agriculture, forestry and fishing. Herewith, the number of people employed in these industries has decreased by 7,200 people in five years. The share of unemployed in rural areas, pursuant to statistical reporting data, is $33 \%$, despite the availability of vacancies in agricultural production, people do not want to work there [1].

This trend continues to persist at the current moment. The main reason for the outflow of the working-age population is the lack of well-paid jobs and the lack of any prospects for the future. Labor resources are redistributed to other spheres, most of all to the service sector, including financial and construction [2].

Based on the analysis of state statistics data, we will consider the main factors affecting the demographic dynamics in the Perm Territory. The number of births in the region decreased by $31 \%$ over 5 years, and the number of deaths also decreased by $8 \%$, but in general, the death rate remains higher than the number of births over three years. As a result of this ratio of births to deaths, the negative value of the indicator of natural growth in rural areas increased 2.6 times (Table 2) [2]. 
Table 2. Indicators of the natural movement of the population of the Perm Territory

\begin{tabular}{|l|c|c|c|c|c|c|}
\hline $\begin{array}{c}\text { Там ворд } \\
\text { корявIndicat } \\
\text { or }\end{array}$ & $\mathbf{2 0 1 5}$ & $\mathbf{2 0 1 6}$ & $\mathbf{2 0 1 7}$ & $\mathbf{2 0 1 8}$ & $\mathbf{2 0 1 9}$ & $\begin{array}{c}\text { Relation of } \\
\mathbf{2 0 1 5} \\
\text { to 2019, \% }\end{array}$ \\
\hline $\begin{array}{l}\text { Total births, } \\
\text { people }\end{array}$ & 38,761 & 37,258 & 31,915 & 29,526 & 26,617 & 68.7 \\
\hline $\begin{array}{l}\text { Total deaths, } \\
\text { people }\end{array}$ & 37,370 & 36,369 & 34,861 & 35,340 & 34,394 & 92.0 \\
\hline $\begin{array}{l}\text { Natural } \\
\text { population } \\
\text { growth, } \\
\text { people }\end{array}$ & 1,391 & 889 & $-2,946$ & $-5,814$ & $-7,777$ & $*$ \\
\hline
\end{tabular}

The development of rural areas today is extremely uneven. Despite the fact that the enterprises of the agricultural complex are increasing the production of their products, the level and life quality of the rural population as a whole lag significantly behind the standard of living in cities.

Insufficient government support, a decrease in the potential of fixed assets, labor, land resources negatively affect the competitiveness of domestic producers. Farms spend a significant portion of their investments on fuel and energy.

The wages in agriculture are $41 \%$ less than the average in the region and 2 times less than the average in Russia. This indicates that agribusiness does not offer competitive salaries to its employees [3].

But there is also a positive trend here: over the past 5 years, the wages of agricultural producers have increased by 8,050 RUR th. However, even considering the development prospects, the level of the average wage of the rural population will not exceed the current level of the average wage of those employed in the economy (Table 3) [4].

Table 3. Dynamics of the average monthly wage per employee, RUR

\begin{tabular}{|l|c|c|c|c|c|c|}
\hline \multicolumn{1}{|c|}{ Indicator } & $\mathbf{2 0 1 5}$ & $\mathbf{2 0 1 6}$ & $\mathbf{2 0 1 7}$ & $\mathbf{2 0 1 8}$ & $\mathbf{2 0 1 9}$ & $\begin{array}{c}\text { Relation of } \\
\mathbf{2 0 1 5} \\
\text { to 2019, \% }\end{array}$ \\
\hline $\begin{array}{l}\text { Average } \\
\text { monthly salary } \\
\text { in Russia }\end{array}$ & 34,030 & 36,709 & 39,167 & 43,724 & 47,468 & 139.5 \\
\hline $\begin{array}{l}\text { Average } \\
\text { monthly salary } \\
\text { in Perm Krai }\end{array}$ & 28,527 & 30,651 & 32,951 & 35,802 & 39,209 & 137.4 \\
\hline $\begin{array}{l}\text { Average } \\
\text { monthly wages } \\
\text { in agriculture in } \\
\text { the Perm } \\
\text { Territory }\end{array}$ & 15,175 & 16,093 & 19,269 & 21,142 & 23,225 & 153.0 \\
\hline $\begin{array}{l}\text { In relation to } \\
\text { the average in } \\
\text { the Perm } \\
\text { Territory, }\end{array}$ & 53.2 & 52.5 & 58.5 & 59.1 & 59.2 & $*$ \\
\hline
\end{tabular}


It should be admitted that the problems hindering the development of rural areas, the standard of living in remote villages contribute to the annual outflow of the population to the cities.

It should be noted that it is the population size that is the budget-forming indicator in the regions and municipalities. This indicator determines the amount of financing of the municipal formation allocated from the federal budget for the execution of powers.

This indicator influences distribution of budget funds to joint financing of actions for development of public infrastructure of regional and municipal value, development of preschool institutions, educational institutions, healthcare institutions and objects of engineering infrastructure. This considers differences in the structure of the population, geographic, climatic, social-and-economic conditions that affect the cost of the provided municipal service per inhabitant.

Most of the indicators for assessing the implementation of the federal program for the development of the education system are calculated considering the number of the population living in the territory. In the sphere of culture, the per capita distribution of financial resources is also used. Per capita standards are used to calculate the financing of health care.

The distribution of subsidized funds for budget equalization depends on the population indicator. Herewith, when calculating the index of budget expenditures, the indicator "Share of the population living in small settlements" is used.

With the outflow of rural residents, funding for rural development decreases. Insufficient financial support of local budgets prevents municipalities from fully resolving issues of local importance (maintenance of schools, hospitals, municipal housing, housing and communal services, roads, transport services). It is not economically feasible to build modern buildings and roads, develop social infrastructure in sparsely populated localities. As a result, there is a decrease in the number of villages and hamlets.

Based on the monitoring of the development of the local self-government system, the number of municipalities decreased by 204 in the region over five years.

As a result of negative dynamics, we observe a tendency for a decrease in the number of municipalities, primarily rural settlements $(-173)$, as well as an increase in the number of urban districts (+18) (Table 4).

Table 4. Dynamics of change in the number of municipalities in the Perm Territory by type as of January 1

\begin{tabular}{|l|c|c|c|c|c|c|}
\hline $\begin{array}{c}\text { Number of } \\
\text { municipalities, } \\
\text { units }\end{array}$ & $\mathbf{2 0 1 6}$ & $\mathbf{2 0 1 7}$ & $\mathbf{2 0 1 8}$ & $\mathbf{2 0 1 9}$ & $\mathbf{2 0 2 0}$ & $\begin{array}{c}\text { Relation } \\
\text { of 2016 to } \\
\mathbf{2 0 2 0} \%\end{array}$ \\
\hline Municipal districts & 40 & 40 & 40 & 32 & 10 & 25 \\
\hline City settlements & 29 & 29 & 29 & 21 & - & $*$ \\
\hline Rural settlements & 260 & 260 & 260 & 213 & 87 & 33.5 \\
\hline Urban districts & 8 & 8 & 8 & 14 & 26 & 325 \\
\hline Municipal districts & - & - & - & - & 10 & $*$ \\
\hline Total & 337 & 337 & 337 & 280 & 133 & 39.5 \\
\hline
\end{tabular}

Herewith, it should be noted that unification processes are taking place only in a small part of the Russian Federation constituent entities. 
Regional specificity influences the development of rural areas as well. Regions dominated by agricultural production are most often subsidized and do not have sufficient financial resources for rural development.

Table 5. Production of food resources in the Perm Territory

\begin{tabular}{|l|c|c|c|c|c|c|}
\hline \multicolumn{1}{|c|}{ Indicator } & $\mathbf{2 0 1 5}$ & $\mathbf{2 0 1 6}$ & $\mathbf{2 0 1 7}$ & $\mathbf{2 0 1 8}$ & $\mathbf{2 0 1 9}$ & $\begin{array}{c}\text { Relation of } \\
\mathbf{2 0 1 5} \text { to } \\
\mathbf{2 0 1 9} \%\end{array}$ \\
\hline $\begin{array}{l}\text { Gross grain harvest, th } \\
\mathrm{t}\end{array}$ & 303.6 & 246.9 & 354.1 & 371.2 & 299.8 & 98.7 \\
\hline $\begin{array}{l}\text { Gross harvest of } \\
\text { potatoes, th t }\end{array}$ & 302.0 & 264.0 & 201.9 & 276.0 & 239.5 & 79.3 \\
\hline $\begin{array}{l}\text { Gross harvest of } \\
\text { vegetables in open } \\
\text { and closed ground, th } \\
\text { t }\end{array}$ & 137.1 & 136.1 & 138.1 & 147.0 & 137.4 & 100.2 \\
\hline Milk production, th t & 474.7 & 475.7 & 483.4 & 505.4 & 529.0 & 111.4 \\
\hline $\begin{array}{l}\text { Production of } \\
\text { livestock and poultry } \\
\text { for slaughter, th t }\end{array}$ & 113.9 & 109.3 & 104.6 & 97.6 & 100.4 & 88.15 \\
\hline $\begin{array}{l}\text { Egg production, mln. } \\
\text { pcs. }\end{array}$ & $1,086.4$ & $1,167.8$ & $1,244.8$ & $1,299.5$ & $1,307.7$ & 120.4 \\
\hline
\end{tabular}

Analyzing the production of food resources in the Perm Territory, we observe a decrease in the production of livestock and poultry for slaughter in five years by $11.9 \%$, unstable indicators of the gross harvest of grain and potatoes, the main reason is the difficult climatic and natural conditions of our region. Herewith, the production of milk and eggs is growing. As a result of the calculations, based on data on the actual and required volume of production of certain types of agricultural products pursuant to consumption standards, in 2019, enough potatoes and chicken eggs were produced in the Perm Territory, in addition, it was possible to supply these products outside the region. The volumes of milk, meat and vegetables produced could not meet the needs of the region's population (Table 5).

The natural and climatic factor is important for the development of agrarian regions. The investment attractiveness of the region, the development of the territory, and ensuring the food security of the country depend on the availability of land resources, a raw material base, conditions for business development.

\section{Discussion}

Insufficient protection of rural residents in the social sphere, low wages, small pensions, lack of work, and frequent alcohol consumption aggravate the problems of rural development. The number of rural residents able to work is declining. The migration outflow of the rural population of working age is growing. All this affects the provision of rural areas with such a paramount factor as labor resources. Pursuant to Rosstat, one third of the outflow of labor resources is compensated by international migration. But due to restrictions due to the threat of the spread of COVID-19 on entering the country, the number of working foreigners has decreased. Herewith, many of them, having registered in rural areas, earn money in cities. In general, this situation accelerates the aging process of the population in rural areas.

One of the main criteria for attracting labor resources to agriculture is to ensure socialand-economic living conditions in the territory. For this purpose, legal acts are adopted in 
the field of rural development at the regional and federal levels. For the implementation of these state programs, the corresponding amounts of funding are laid, which are growing every year.

One of the main goals of these programs is the development of rural areas, and the tasks are to develop human resources, address social issues, infrastructure, and increase the prestige of the agricultural sector.

However, despite the state support of rural areas, it was not possible to radically change the living conditions of the population in rural areas. Dmitry Patrushev, the head of the Ministry of Agriculture, said at a meeting on the current state of affairs in the development of non-urban areas that more than $67 \%$ of the housing stock in rural areas is not equipped with all types of amenities, and in the city - below $21 \%$ [5].

In 2020, the federal program "Comprehensive Development of Rural Areas" began to work, pursuant to which budget funds are distributed to rural areas where investment projects in the agro-industrial complex are being implemented, with the attraction of additional funding from extra-budgetary sources, new jobs are created. And the settlements in which there is a high level of unemployment, low wages of the population and no agricultural production, cannot attract funds from other budgets.

\section{Conclusion}

We believe that all of the above factors indicate that the modern development of rural areas is accompanied by many contradictions. And most of the factors that determine the development of rural areas today have a negative impact. We are afraid that the further development of the negative phenomena and processes described above may lead to the loss of villages in the near future. Therefore, we consider it necessary to take state measures that will be aimed at the growth of the agrarian economy, increasing the level and life population quality, lowering the poverty level of rural residents, raising a new, positive image of rural life.

We recommend developing a strategy for the development of rural areas pursuant to the following development directions:

- economic (resources, investments, fiscal potential, competitive advantages, diversification of the rural economy, development mechanisms, employment of the population);

- socio-demographic (social and engineering infrastructure, education, health care, culture and sports services, the formation of a positive image of life in the countryside);

- administrative (support for local initiatives, efficiency of municipal property management, efficiency of expenditures of municipalities, consistency of interests of the federal and regional levels, considering the peculiarities of rural areas).

If funds are distributed to the territories in proportion to the number of residents, municipalities will have the opportunity to choose initiative projects based on the needs of the population. Issues such as access to the Internet, street lighting, installation of electricity, water and gas will be able to be resolved.

It is worth noting that the industry, which prevails there, has a great influence on the development of the territory. Nowadays, agritourism is increasingly influencing the development of the village. The Perm Territory is rich in natural and historical sights and has great potential for the development of domestic tourism.

Attracting temporary residents from cities: tourists, summer residents (for the summer season or a day off) will attract additional funds for the development of the territory. Agritourism will assist in ensuring economic and demographic stability in the countryside and may become an effective tool for the future development of rural areas.

In addition, the pandemic made some urban residents think about moving to a new place of residence in an area with a lower population density. Many employees switched to a 
remote mode of work, in connection with which there were problems of creating additional zones in small apartments (creating a workplace, conditions for playing sports). Private houses and summer cottages have become very popular among the townspeople. Small towns and rural settlements have become promising ways to protect against large gatherings of people. We hope that the preference for urban residents to live in rural areas will reduce the high population density of megacities and accelerate the social-andeconomic development of rural areas.

\section{References}

1. A.A. Dadashev-Ogly., I.A. Dikareva, Vestnik Akademii znanij, 4(39), 149 (2020)

2. Monitoring o razvitii sistemy mestnogo samoupravleniya v Rossijskoj Federacii http://minjust.ru/ru/press/news/monitoring-razvitiya-sistemymestnogosamoupravleniya

3. N.V. Mkrtchyan, Population and Economics, 1, 39 (2019)

4. Oficial'naya statistika, Naselenie, Federal'naya sluzhba gosudarstvennoj statistiki (Rosstat)

http://www.gks.ru/wps/wcm/connect/rosstat_main/rosstat/ru/statistics/population/ M. Parry, C. Rosenzweig, A. Iglesias, GlobalEnvironmentalChange, 9, 51 (1999)

5. Permskij kraj v cifrah 2020, Permstat.gks.ru, https://permstat.gks.ru/storage/mediabank/UD9sVzqx/Permskij\%20kraj\%20v\%20cifra $\mathrm{h} \% 202020 . \mathrm{pdf}$

6. Ob utverzhdenii gosudarstvennoj programmy «Gosudarstvennaya podderzhka agropromyshlennogo kompleksa Permskogo kraya ot 03.10.2013 g. № 1320, Postanovlenie Pravitel'stva Permskogo kraya http://www.consultant.ru

7. Ob utverzhdenii gosudarstvennoj programmy Rossijskoj Federacii «Kompleksnoe razvitie sel'skih territorij» $\mathrm{i}$ o vnesenii izmenenij v nekotorye akty Pravitel'stva Rossijskoj Federacii ot 31.05.2019 g. № 696, Postanovlenie Pravitel'stva Rossijskoj Federacii, http://www.consultant.ru 9.

8. Statistika Rossii i mira - informaciya i pokazateli, https://rosinfostat.ru/

9. Statistika, http://old.gks.ru/

10. T.M. YArkova, Kreativnaya ekonomika, 2, 379 (2021) 